\title{
Characteristics of Concrete Modified with Ground Granulated Blast-Furnace Slag (GGBS) as Binding Material
}

\author{
Jawad Ahmad ${ }^{1 *}$ Aneel Manan ${ }^{1}$, Muhammad Asim ${ }^{2}$, Shaheed Ullah ${ }^{3}$, Rahat Ullah ${ }^{2}$, Asif Ali ${ }^{1}$. \\ ${ }^{1}$ Department of Civil Engineering, Swedish College of Engineering and Technology, Wah Cantt, Pakistan. \\ ${ }^{2}$ Department of Civil Engineering, Military College of Engineering, Risalpur, Pakistan. \\ ${ }^{3}$ Department of Civil Engineering, Capital University of Science and Technology, Islamabad, Pakistan. \\ Corresponding author email: jawadcivil13@scetwah.edu.pk
}

\begin{abstract}
The industrial waste has been rapidly increased day by day because of the fast-expanding population which dumps the waste in an inappropriate way resulting in environmental pollutions. It has been recommended that; the disposal of industrial waste would be greatly reduced if it could be incorporated in concrete production. Among these waste, one option is the replacement of cement by slag, which causes in the decrease of consumption of cement, reduction in emissions of $\mathrm{CO}_{2}$, while solve a waste management issue. The basic objective of this investigation is to examine the characteristics of concrete using Ground granulated blast-furnace slag (GGBS) as binding material in proportions $0 \%, 10 \%, 20 \%, 30 \%, 40 \% \& 50 \%$ by weight of cement. Several properties have been reviewed in the current paper. The results observed from slump test depict that replacement of Ground granulated blast-furnace slag (GGBS) increased slump of concrete. The tests result also depict that GBBS enhances strength (compressive, split tensile and flexure strength) of the concrete up to $30 \%$ substitution and beyond $30 \%$ substitution, the strength starts to fall gradually. Therefore, it is recommended to used steel fibers up 30\% by weight of cement to achieved maximum benefits.
\end{abstract}

Key words: GBBS, waste materials, binding materials, slump, sustainable concrete, mechanical strength.

\section{INTRODUCTION}

Blast-furnace slag is a material which is rich in amorphous calcium, alumina, \&, silica which set up it appropriate to be used as a binder (adhesive) in the construction industry [1]. Blast-furnace slag is mainly used in different engineering areas to substitute the Portland cement [2].Slag is attained through steel production \& is allegedly used in concrete due to decrease porosity \& promotes endurance by developing the connection with crush. Environmental \& financial merits in shape of resource-preserving \& energy-efficient features can also be obtained using slag-mixed cement [3]. Also, the long-term \& mechanical material features as comparison to those of Portland cement concrete, onwards with its ecological friendliness \& cost- efficiency, (GGBS)-based upon geo-polymer concrete has turn out an alluring target to investigators as an complementary structural material to cement [5].Since the Ground granulated blast-furnace slag is affluent in calcium $(\mathrm{Ca})$, the key reaction creation is C-S-H (Calcium silicate hydrate) gel, which can cohabit with the geo-polymer gel depend on the chemical structure of (GGBS), alkali amount, \& alkali type [6].Qiu, Zhao [7] in their research, the strength raises \& the mix gets more consistent as the ratio of Ground granulated blast-furnace slag to fly ash raises because of the raise (calcium silicate hydrate) merging. Addition of superfine (GGBS) can form the self-compacting concrete hit a greater level of strength [8]. Chemical structure, hydration characteristics, water demand, $\&$ particle morphology of various (GGBS) were studied. The outcome displayed that there was no major difference in the chemical structure \& grain arrangement of (GGBS) with changes to the (GGBS) grain extent, \& also displayed that alter ratio of water required $\&$ the intensity altered quickly with the modified of (GGBS) particles[9]. Investigated the consequence of ground nano-slag GNS on the porosity resistance, absorption, \& compressive strength, to chloride ion piercing concrete of high strength. Investigators established that durability and strength of high strength concrete were finest when the ground nano slag proportion was ten percent. Similarly, lower rate (5 percent) of the GNS is not nicely scattered $\&$ is not ample to acquire strength. High rate (15 percent) of GNS steers to raise in aggregated ultra-fine grain capacity of concrete $\&$ the inappropriate pore filling [10]. An experimental study was conducted on the elastic modulus, flexural strength, compressive strength, chloride ion relocation, \& concrete ability to resist blended with fine (ultra) slag dust. This was established that concrete blended with fine (ultra) slag dust powder has more strength (early), better durability, \& lesser porosity at 3 days of curing age[11].There are investigations based on the replacements of cement by GGBFS [12]. Even scoring up to 80 percent of the cement cut off by this type of slag. Khatib et al [13] substituted up to 80 percent of cement by (GGBS) slag

forming various replacements. Better outcomes were achieved in the replacements up to 60 percent, since compressive strengths alike to common concrete were achieved. After 28 \& 90 days, the strength was raised. 
Jawad Ahmad et al., International Journal of Emerging Trends in Engineering Research, 8(8), August 2020, 4711 - 4718

However, poor outcomes were achieved when substituting 80 percent of the slag, \& in the $1^{\text {st }}$ days of setting, the strength of the control concrete was not acquired. Beushausen et al.[14] Realized, under damp curing environment \& when the slag substitute rate is lower than 50 percent, the one day concrete early age strength approximately directly reduces with the raise in the slag substitute rate. At ages of $28 \& 56$ days, because to the creation of calcium silicate hydrate from the slag reaction, the compressive strength of concrete with mixed slag can exceed that of reference concrete. As a finite number of researches have been performed on the split tensile $\&$ compressive strengths of (GGBS) based geo-polymer concrete composite mixed with (GGBS). In this research, the impact of various factors on the hardened and fresh features of GPCC was noticed. Set on test outcomes, the performance of concrete is considerably improved with incorporation of GGBFS.

\section{MATERIALS AND EXPERIMENTAL PROGRAM}

\subsection{CEMENT}

Accordance to ASTM C150 [15], Ordinary Portland cement (OPC) type-1 with 28 days compressive strength $42 \mathrm{Mpa}$ and specific surface $322 \mathrm{~m}^{2} / \mathrm{kg}$ was used in this study. Furthermore, its chemical and physical properties are displayed in Table 1.

\subsection{AGGREGATE}

Natural sand was used as a FA in all the mixes in saturated surface dry) condition. Normal weight crush stone was used as coarse aggregate in saturated dry condition (SSD) which was obtained from Margallah Wah cantt Punjab Pakistan.

Table 2 : Properties of Aggregate

\begin{tabular}{|c|c|c|}
\hline $\begin{array}{c}\text { Physical } \\
\text { Property }\end{array}$ & Fine aggregate & $\begin{array}{c}\text { Coarse } \\
\text { Aggregate }\end{array}$ \\
\hline Particle Size & $\begin{array}{c}4.75 \mathrm{~mm} \text { to } \\
0.075 \mathrm{~mm}\end{array}$ & $\begin{array}{c}19.5 \mathrm{~mm} \text { to } \\
4.75\end{array}$ \\
\hline $\begin{array}{c}\text { Fineness } \\
\text { Modulus }\end{array}$ & 2.63 & 4.23 \\
\hline $\begin{array}{c}\text { Absorption } \\
\text { Capacity }\end{array}$ & $4.08 \%$ & $2.9 \%$ \\
\hline $\begin{array}{c}\text { Moisture } \\
\text { Content }\end{array}$ & $1.8 \%$ & $1.2 \%$ \\
\hline $\begin{array}{c}\text { Bulk density } \\
(\mathrm{kg} / \mathrm{m} 3)\end{array}$ & 1566 & 1575 \\
\hline
\end{tabular}

Nominal maximum size of coarse aggregate was 19 . $5 \mathrm{~mm}$.Different tests were performed on aggregate to evaluate its physical property as shown in Table 2.

\subsection{GROUND GRANULATED BLAST-FURNACE SLAG (GGBS)}

GGBS is financially accessible in high amounts \& suitable for making of high amount of ready-mix concrete at site in precast product assembly. The granulated slag is dried \& ground to a fine powder which is called Ground-granulated blast-furnace slag. It is white in color \& has a bulk density of $1200 \mathrm{~kg} / \mathrm{m}^{3}$.The physical properties \& chemical ingredients of GGBS are given in Table 3.

Table 1: Physical and Chemical Property of OPC

\begin{tabular}{|c|c|c|c|}
\hline $\begin{array}{c}\text { Chemical } \\
\text { Property }\end{array}$ & $\begin{array}{c}\text { Percentage } \\
(\%)\end{array}$ & $\begin{array}{c}\text { Physical } \\
\text { Property }\end{array}$ & Results \\
\hline $\mathrm{Ca} 0$ & 66.7 & Size & $\leq 75 \mu$ \\
\hline $\mathrm{SiO} 2$ & 26.9 & Fineness & $94 \%$ \\
\hline $\mathrm{A} 2 \mathrm{O} 3$ & 6.4 & $\begin{array}{c}\text { Normal } \\
\text { Consistency }\end{array}$ & $28 \%$ \\
\hline $\mathrm{Fe} 2 \mathrm{O} 3$ & 4.7 & $\begin{array}{c}\text { Initial } \\
\text { Stetting Time }\end{array}$ & $36 \mathrm{~min}$ \\
\hline $\mathrm{MgO}$ & 4.5 & $\begin{array}{c}\text { Final } \\
\text { Stetting Time }\end{array}$ & $418 \mathrm{~min}$ \\
\hline $\mathrm{SO} 3$ & 2.9 & $\begin{array}{c}\text { Specific } \\
\text { surface }\end{array}$ & $322 \mathrm{~m}^{2} / \mathrm{kg}$ \\
\hline $\mathrm{K} 2 \mathrm{O}$ & 1.4 & $\begin{array}{c}\text { Soundness } \\
28-d a y s\end{array}$ & $1.60 \%$ \\
\hline $\mathrm{Na} 2 \mathrm{O}$ & 0.2 & $\begin{array}{c}28 \text { compressive } \\
\text { Strength }\end{array}$ & $42 \mathrm{Mpa}$ \\
\hline
\end{tabular}

Table 3 : Properties of GBBS

\begin{tabular}{|l|c|l|l|}
\hline $\begin{array}{l}\text { Chemica } \\
\text { Property }\end{array}$ & $\begin{array}{c}\text { Percentage } \\
(\%)\end{array}$ & $\begin{array}{l}\text { Physical } \\
\text { Property }\end{array}$ & Results \\
\hline $\mathrm{Ca} 0$ & 51.55 & Color & White \\
\hline $\mathrm{SiO} 2$ & 8.13 & $\begin{array}{l}\text { Specific } \\
\text { Gravity }\end{array}$ & 2.20 \\
\hline $\mathrm{A} 2 \mathrm{O} 3$ & 21.20 & Type & $\mathrm{F}$ \\
\hline $\mathrm{Fe} 2 \mathrm{O} 3$ & 5.23 & Clay $(\%)$ & 0.9 \\
\hline $\mathrm{MgO}$ & 2.32 & $\begin{array}{l}\text { Bulk } \\
\text { density } \\
\text { (kg/m3) }\end{array}$ & 1200 \\
\hline $\mathrm{SO} 3$ & 1.07 & & \\
\hline $\mathrm{K} 2 \mathrm{O}$ & 1.9 & & \\
\hline $\mathrm{Na} 2 \mathrm{O}$ & 2.6 & & \\
\hline
\end{tabular}




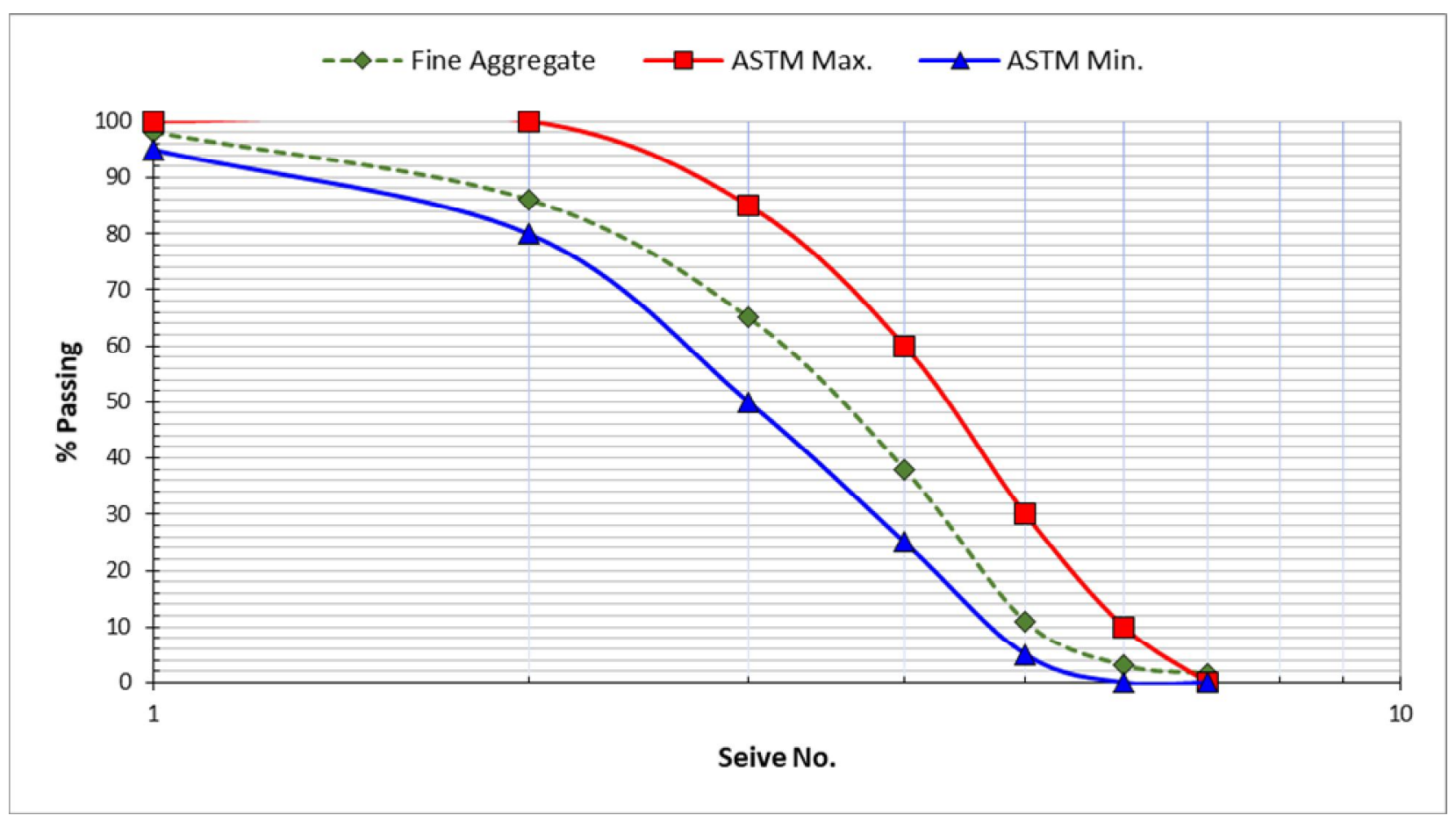

Figure 1 : Gradation Curve Fine Aggregate

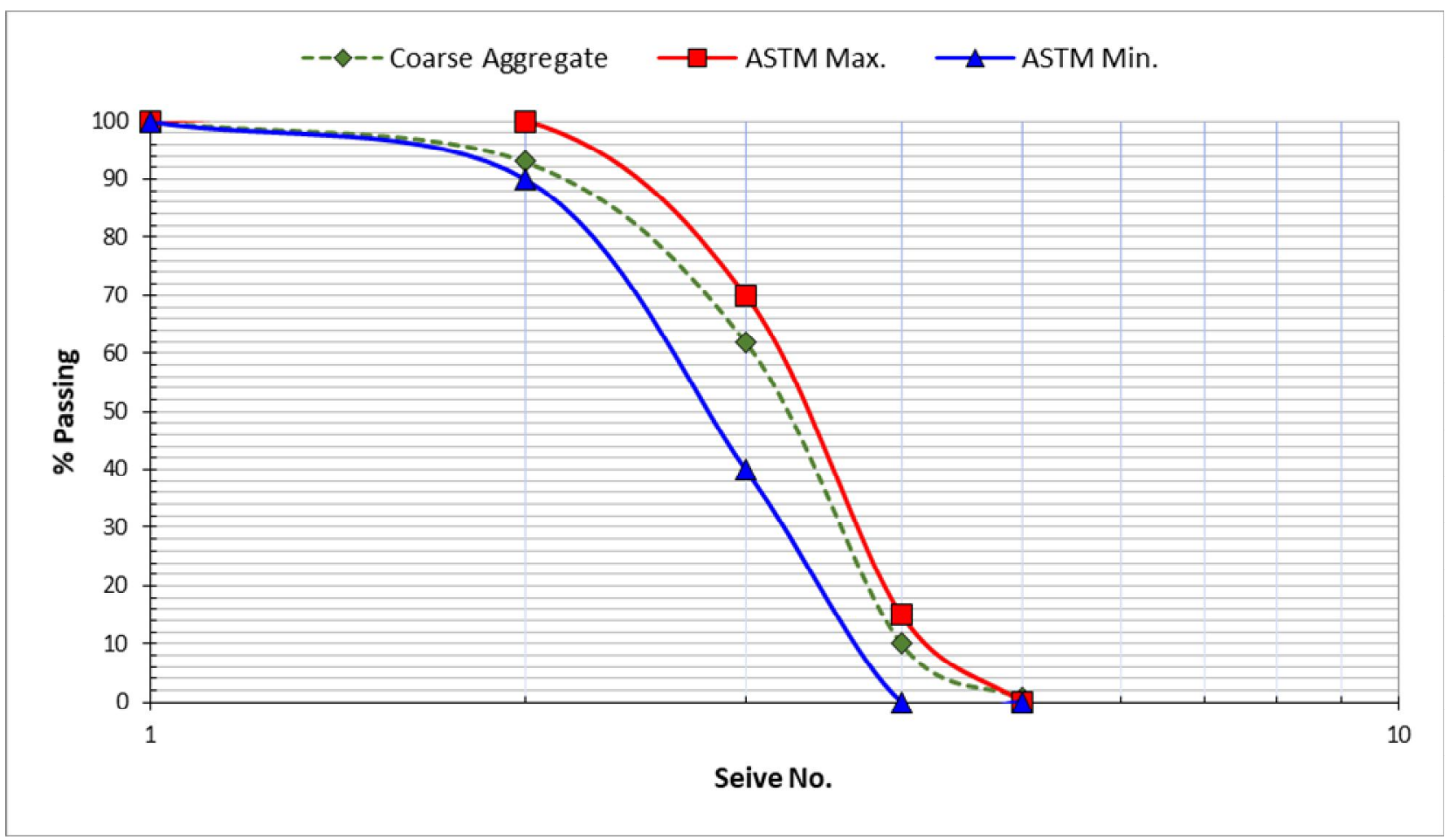

Figure 2 : Gradation Curve of Coarse Aggregate 
Jawad Ahmad et al., International Journal of Emerging Trends in Engineering Research, 8(8), August 2020, 4711 - 4718

\subsection{SIZE OF SPECIMEN}

Slump cone was used to determine the workability of fresh concrete as per ASTM [16]. ASTM C39/C39M [17] Cylinder of standard size (6x12in) will be used to measure the compressive strength at 7 days $\& 28$ days. Similar cylinders of standard size $(6 \times 12$ in $)$ will be cast and tested to find their tensile strength. Beam of size $(4 \times 4 \times 12$ in $)$ will be casted and tested to find their flexure strength as per ASTM [18]. Three specimens are tested for each test at 7 and 28 days and the mean value of the specimens is considered as strength.

\subsection{SAMPLE PREPARATION METHOD}

ASTM C-31[19] method was followed for the preparation of the specimens and compaction was done manually by Roding in three layers having 25 blows per layer. A total of 162 samples having a standard size will be cast \& then will be tested. To study the effect of GGBS on the behaviors of hardened and fresh concrete, six mixes were prepared with varying dosages of Ground granulated blast-furnace slag (GGBS) as binding material in proportions $0 \%, 10 \%, 20 \%$, $30 \%, 40 \%$ \& $50 \%$ by weight of cement. Details of the mixes were provided in Table 4 .

Table 4: Quantification of materials

\begin{tabular}{|c|l|l|l|l|l|l|}
\hline Materials & Mix 1 & Mix 2 & Mix 3 & Mix 4 & Mix 5 & Mix 6 \\
\hline Cement & 1 & 1 & 1 & 1 & 1 & 1 \\
\hline Sand/F. A & 1.5 & 1.5 & 1.5 & 1.5 & 1.5 & 1.5 \\
\hline Coarse Aggregate & 3 & 3 & 3 & 3 & 3 & 3 \\
\hline W/C & 0.50 & 0.50 & 0.50 & 0.50 & 0.50 & 0.50 \\
\hline Superplasticizer & $1 \%$ & $1 \%$ & $1 \%$ & $1 \%$ & $1 \%$ & $1 \%$ \\
\hline GGBS & $0 \%$ & $10 \%$ & $20 \%$ & $30 \%$ & $40 \%$ & $50 \%$ \\
\hline
\end{tabular}

\section{RESULTS AND DISCUSSION}

\subsection{SLUMP}

Consistency of fresh concrete is a mix feature which includes the various provisions of mobility, stability, finish ability, compatibility and place ability [20]. Slump value with varying dosage of GGBS were show in Figure 3. Workability of Concrete decreased as the percentage of GGBS increased. Slump value of $0 \%, 10 \%, 20 \%, 30 \%, 40 \%$ and $50 \%$ of GGBS added to concrete mixes were $63 \mathrm{~mm}, 57 \mathrm{~mm}, 48 \mathrm{~mm}, 40 \mathrm{~mm}$, $35 \mathrm{~mm}$ and $28 \mathrm{~mm}$ which were $20 \%, 35 \%, 43 \%, 45 \%$ and $47 \%$ lower than from reference concrete as shown in Figure 3. The increased in slump value could be attributed due to smooth and fine particle of GGBS. The fine particle of GBBS fills the gap between aggregate sand and cement which facilitate better flow of cement concrete due less water is required for lubricant and as a result slump value increased. It has been also noticed that raise in slump value was reported while the substitution ratio raised for GGBS [21].

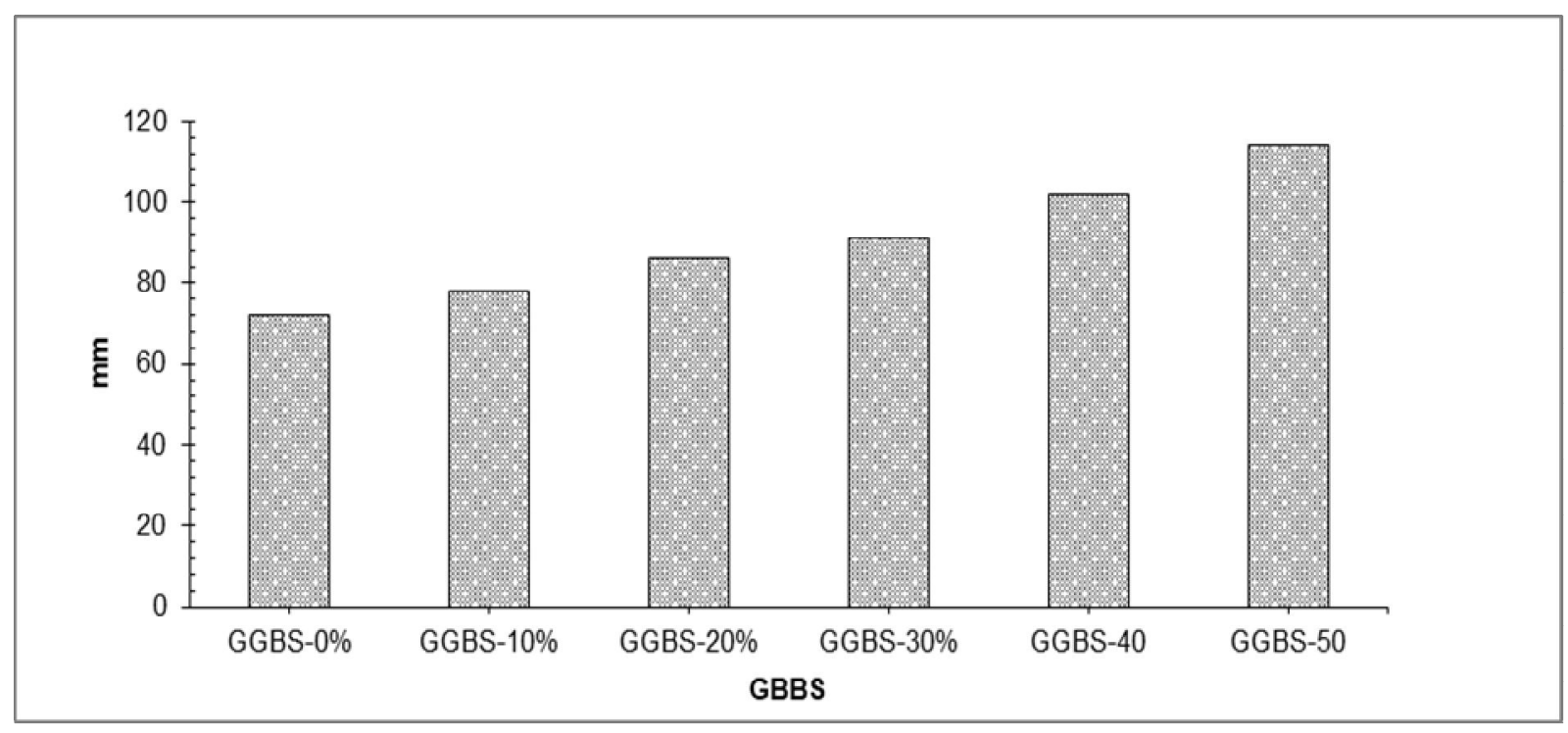

Figure 3 : Slump Test Results 


\subsection{COMPRESSIVE STRENGTH}

Compressive strength is the property of material to resist stresses when it is compressed. The compressive strength test was done with compliance to the standard procedure of ASTM as ASTM C39/C39M [17] for cylindrical specimens having standard dimensions as 6 inches diameter and 12 inches length.

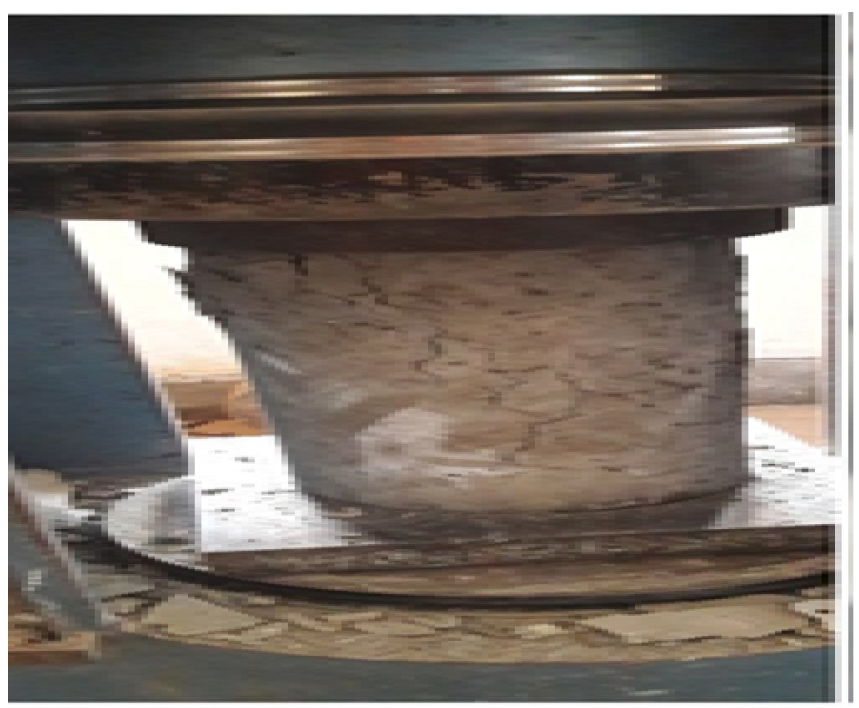

Figure 4 : Setup for Compressive Strength
Figure 5 Shows Compressive strength of various GGBS blends of concrete. As the level of substitution rises the early-age strength (7 days) reduces. Anyway, prolonged strength (28 and 56 days) increased as the percentage of GBBS increased up to $30 \%$ substitute and then gradually decrease as shown in Figure 5. This could be because of the dilution effect and low pozzolanic reaction [22]. With the raising specified surface area of (GGBS), the portion of fine grains of (GGBS) raises, which leads to a more consistent and sounder filling of cement grains pores. The greater the surface area, higher the ability of reaction whiles the rapid the reaction process, the more thorough the reaction $\&$ greater the concrete. At the same time, the fine slag grains which are not tangled in the reaction of hydration are consistently distributed in the voids, however the gel body, which behaves to fill the voids \& cracks of pore, improve the pore composition \& better the cement stone compactness. Also, the finer mineral dust powder grains behave as a frame of the micro-aggregate, so that the Cementitious (binding) material has a good grain distribution, creating a self-tight packing system with a meso-level layer \& compact filling structure, The gel composition is more improved, \& the interfacial binding $\mathrm{b} / \mathrm{w}$ the microstructure $\&$ the aggregates of the mortar is enhanced, therefore developing the macroscopic depiction of the concrete [23]. The optimum dosages of GBBS in This research is $30 \%$ by weight of cement. Therefore, it is recommended to used GBBS up to $30 \%$ by weight of cement to obtain maximum compressive strength.

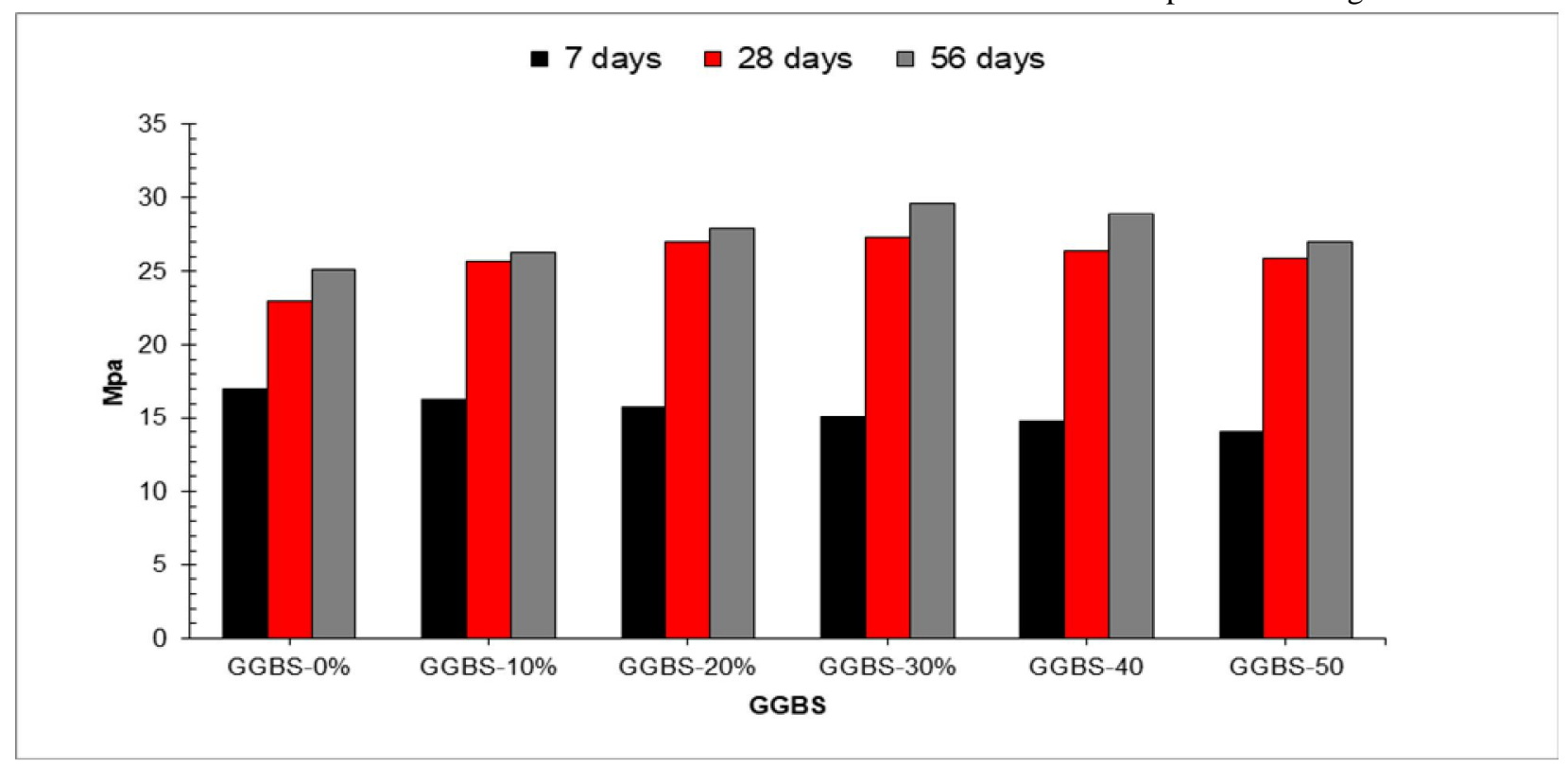

Figure 5 : Compressive Strength Test Results

\subsection{SPLIT TENSILE STRENGTH}

Tensile strength of concrete is the tensile stresses generated due to applying of the compressive load at which the concrete sample may fail. According to ASTM C496-71[24], split tensile test was performed on cylindrical samples of $300 \mathrm{~mm}$ height $\& 150 \mathrm{~mm}$ diameter at the ages of 7, $28 \& 56$ days curing. 

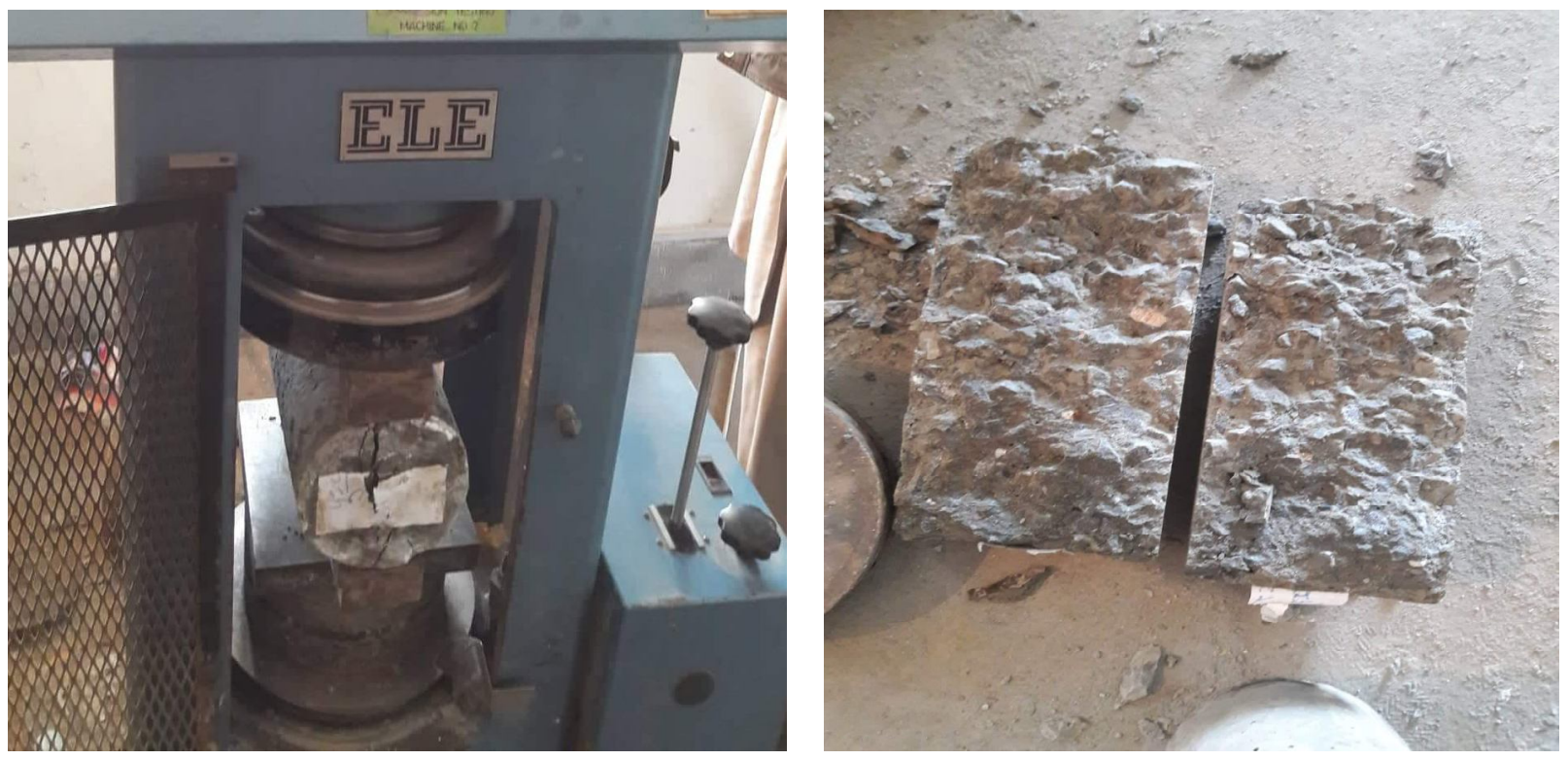

Figure 7 : Setup for Split Tensile Strength

Figure 6 shows split tensile strength of different GGBS mixes of concrete. Like Compressive strength, as the rate of substitution raises the early-age strength (7days) reduces. Although, prolonged strength(28 and 56 days) increased as the percentage of GGBS increased up to $30 \%$ substitute and then gradually decrease as shown in Figure 6.This could be because of the dilution effect and low pozzolanic reaction [22]. All mixes of GBBS Concrete show greater strength than reference mix at the age $28-\& 56$-days curing. The maximum Split tensile strength was obtained at $30 \%$ of GBBS. Therefore, it is recommended to used GBBS instead of cement up to $30 \%$ substitution by considering the mechanical performance of concrete.

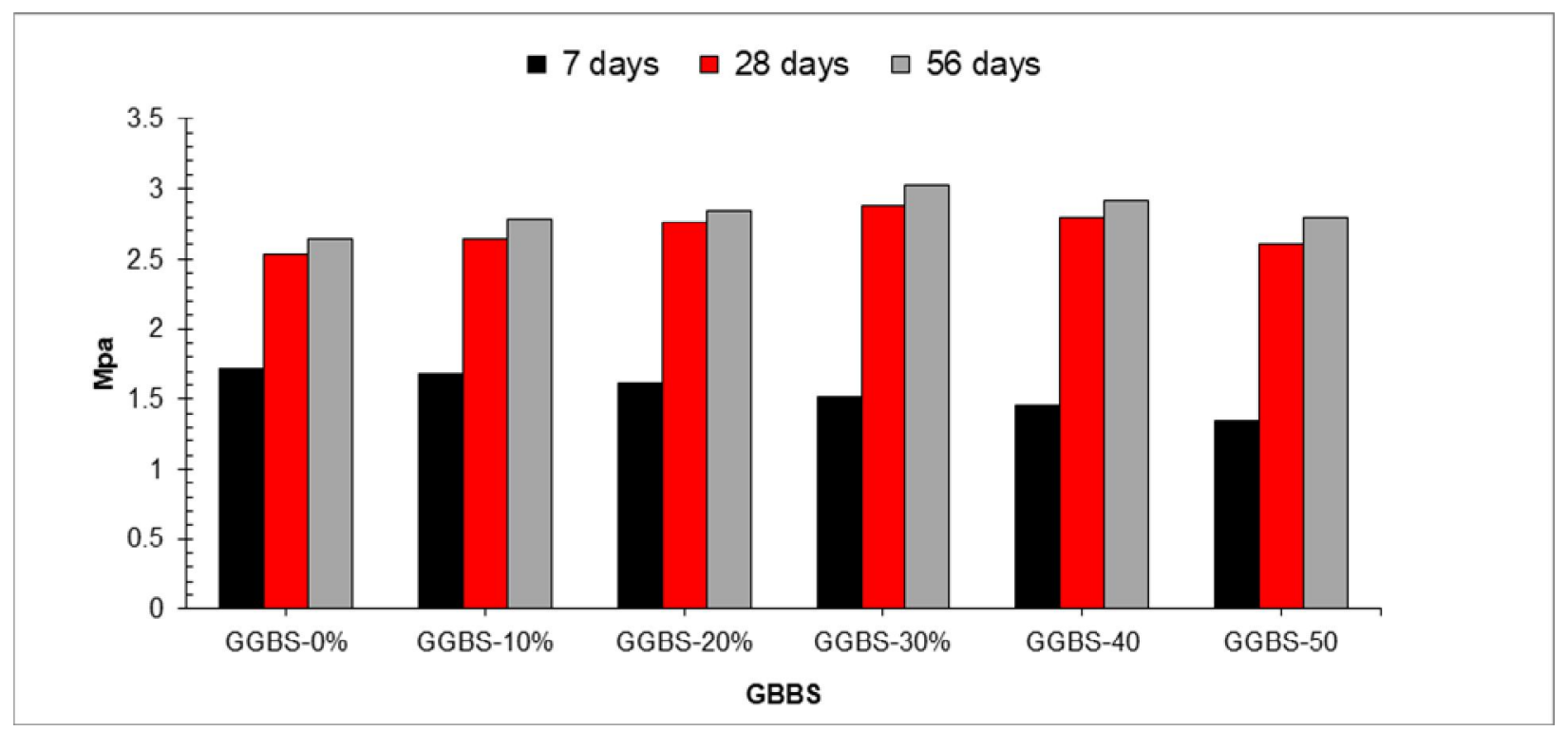

Figure 6 : Split Tensile Strength Test Results

\subsection{FLEXURE STRENGTH}

Flexural test determines the tensile strength of concrete. It is studies the capacity of unreinforced concrete slab or beam to the resist yielding in bending
According to ASTM C78 [18], flexure test was performed beam samples of $100 \times 100 \times 300 \mathrm{~mm}$ at the ages of 7, 28 and 56 days curing 


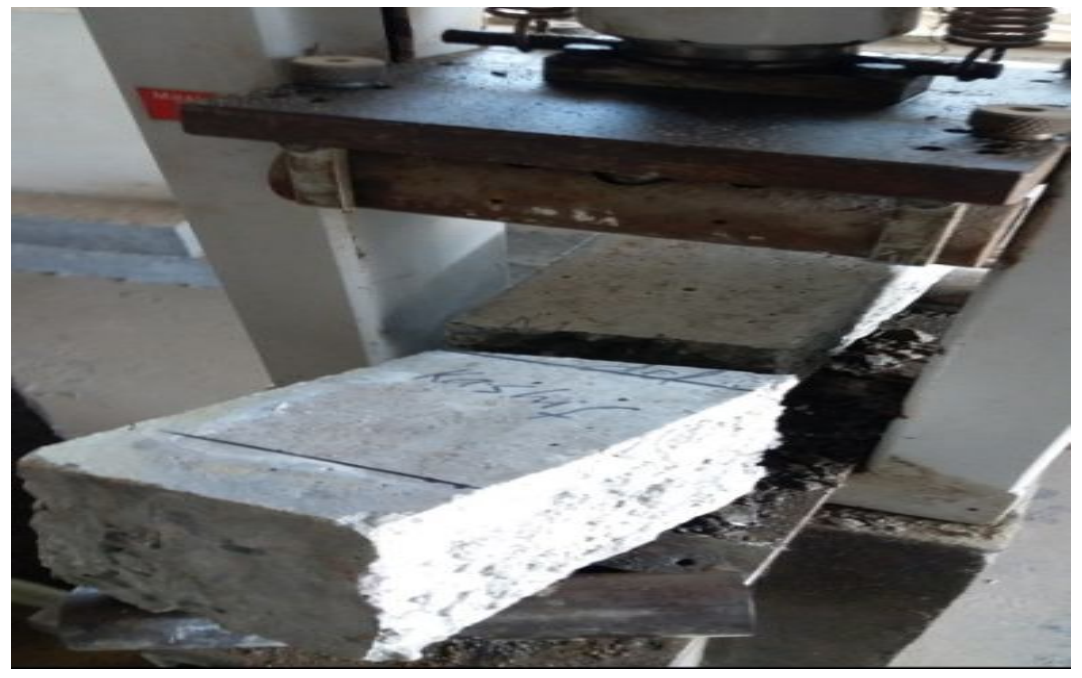

Figure 8 : Setup for Flexure Strength

curing. It is due to the

Figure 9 Shows flexure strength of different GGBS mixes of concrete. Like Compressive strength, as the rate of substitution raises, the early-age strength reduces while long term strength increased as the percentage of GGBS increased up to $30 \%$ substitute and then gradually decrease as shown in Figure 9. Maximum flexure strength was obtained at 30\% substitution of GGBS while minimum flexure strength was obtained at $0 \%$ substitution of GGBS (blank/control mix) at 28- and 56-days curing. All mixes of GBBS Concrete show greater strength than reference mix at the age 28- and 56-days pozzolanic reaction of $\mathrm{Sio}_{2}$ in FA with $\mathrm{Ch}$ of cement making extra Cementitious components. The extra binder created by the GBBS reaction with available lime let GBBS concrete to continue to obtain strength over time. It is well known that Pozzolanic reaction does not contribute at early ages, however that appears to offset this trend at a later age of hardening and as such provides to enhancement in the compressive strength at 28 and 56 days.

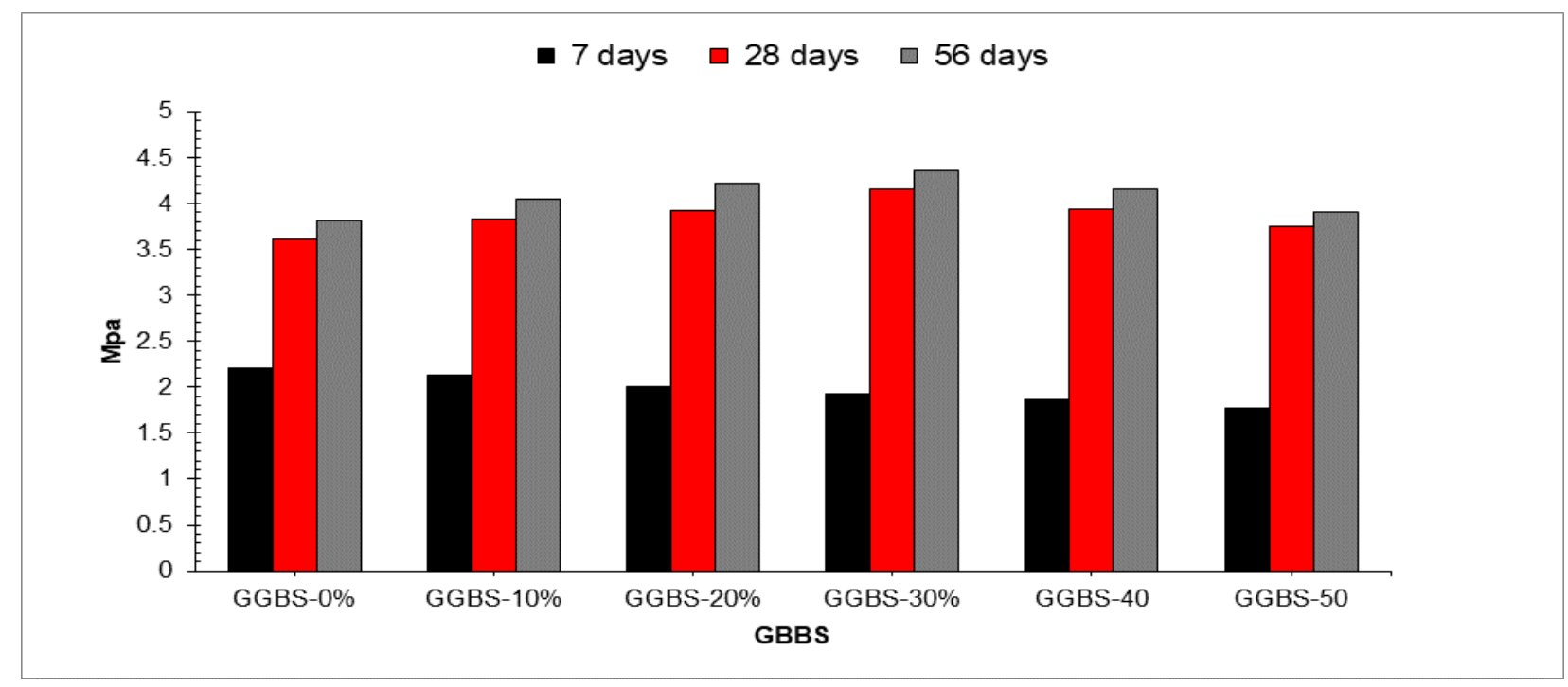

\section{CONCLUSIONS}

In this research Ground granulated blast-furnace slag (GGBS) was used as a binding material in proportion of $0 \%$, $10 \%, 20 \%$

Figure 9 : Flexure Strength Results

$30 \%, 40 \%$ and $50 \%$ by weight cement. Based on experimental work following conclusion has been drawn.

- Workability of concrete increased as percentage of GBBS increased. Highest slump was achieved at $50 \%$ substitutions of GBBS. It is due fact that GBBS 
Jawad Ahmad et al., International Journal of Emerging Trends in Engineering Research, 8(8), August 2020,4711 - 4718

fills voids in between sand and coarse aggregate.so more paste is available for lubricant.

Strength (compressive, flexure and split tensile) increased up to $30 \%$ substitution of GBBS and beyond $30 \%$ the strength gradually decreased. It is due to fact that GBBS as a micro filler, which fills the voids in sand and coarse aggregate, giving more dense concrete which results to enhance the mechanical performance.

- It can be concluded that, GBBS as binding material (cement) can be used to improve the mechanical properties of conventional concrete. From the economic and environmental point of view this waste can be successfully used as binding material in concrete production.

\section{REFERENCES}

1. Aydin S, Baradan B (2014) Effect of activator type and content on properties of alkali-activated slag mortars. Compos Part B Eng 57:166-172. https://doi.org/10.1016/j.compositesb.2013.10.001

2. Flynn RT, Grisinger TJ, Mather B, et al (2003) Slag Cement in Concrete and Mortar. Am Concr Inst Farmingt Hills, MI, USA. https://doi.org/10.1016/s0008-8846(03)00277.

3. Wang X-Y, Lee H-S (2010) Modeling the hydration of concrete incorporating fly ash . Cem Concr Res 40:984-996.

https://doi.org/10.1016/j.cemconres.2010.03.001

4. Naik TR (2008) Sustainability of concrete construction. Pract Period Struct Des Constr 13:98-103

5. Sumajouw DMJ, Hardjito D, Wallah SE, Rangan B V (2007) Fly ash-based geopolymer concrete: study of slender reinforced columns. J Mater Sci 42:3124-3130.

6. Glukhovskij V, Zaitsev Y, Pakhomov V (1983) Slag-alkaline cements and concretes-structure, properties, technological and economical aspects of the use. Silic Ind 48:197-200.

7. Qiu J, Zhao Y, Xing J, Sun X (2019) Fly ash/blast furnace slag-based geopolymer as a potential binder for mine backfilling: Effect of binder type and activator concentration. Adv Mater Sci Eng

8. Mohan A, Mini KM (2018) Strength Studies of SCC Incorporating Silica Fume and Ultra Fine GGBS. Mater Today Proc 5:23752-23758

9. Zhang T-S, Yu Q-J, Wei J-X, et al (2011) Effect of size fraction of ground granulated blast furnace slag on its strength contribution and hydraulic activity. Adv Sci Lett 4:1286-1291. https://doi.org/10.1166/asl.2011.1733

10. Sharmila P, Dhinakaran G (2016) Compressive strength, porosity and sorptivity of ultra fine slag based high strength concrete. Constr Build Mater 120:48-53

11. Teng S, Lim TYD, Divsholi BS (2013) Durability and mechanical properties of high strength concrete incorporating ultra fine ground granulated blast-furnace slag. Constr Build Mater 40:875-881.

https://doi.org/10.1016/j.conbuildmat.2012.11.052

12. Oner A, Akyuz S (2007) An experimental study on optimum usage of GGBS for the compressive strength of concrete. Cem Concr Compos 29:505-514.

https://doi.org/10.1016/j.cemconcomp.2007.01.001

13. Khatib JM, Hibbert JJ (2005) Selected engineering properties of concrete incorporating slag and metakaolin. Constr Build Mater 19:460-472. https://doi.org/10.1016/j.conbuildmat.2004.07.017

14. Beushausen H, Alexander M, Ballim Y (2012) Early-age properties, strength development and heat of hydration of concrete containing various South African slags at different replacement ratios. Constr Build Mater 29:533-540. https://doi.org/10.1016/j.conbuildmat.2011.06.018.

16. Grout F ASTM C 476, except with a maximum slump of 4 inches, as measured according to ASTM C 143. C 143M

17. C39/C39M A (2003) Standard test method for compressive strength of cylindrical concrete specimens. Annu B ASTM Stand.

18. Standard A (2010) C78. 2010. Stand Test Method Flexural Strength. Simple Beam with Third-Point Load (ASTM C78-10) West Conshohocken, PA ASTM Int

19. Specimen CT ASTM C 31; one set of four standard cylinders for each compressive-strength test, unless otherwise directed. Mold store Cylind Lab test specimens Except when field-cured test specimens are required

20. Aggarwal Y, Siddique R (2014) Microstructure and properties of concrete using bottom ash and waste foundry sand as partial replacement of fine aggregates. Constr Build Mater 54:210-223. https://doi.org/10.1016/j.conbuildmat.2013.12.051

21. Yuksel I, Genç A (2007) Properties of concrete containing nonground ash and slag as fine aggregate. ACI Mater J 104:397. https://doi.org/10.14359/18829

22. Bouzoubaa N, Zhang M-H, Malhotra VM (2001) Mechanical properties and durability of concrete made with high-volume fly ash. Cem Concr Res 31:1393-1402.

https://doi.org/10.1016/s0008-8846(01)00592-0

Khan K, Amin MN (2017) Influence of fineness of volcanic ash and its blends with quarry dust and slag on compressive strength of mortar under different curing temperatures. Constr Build Mater 154:514-528.https://doi.org/10.1016/j.conbuildmat. 2017.07.214

24. Designation A (1976) C496-71. Stand Method Test Split Tensile Strength Cylind Concr Specimens. 